\title{
PENGARUH JALAN KAKI DUA PULUH MENIT TERHADAP PENURUNAN TEKANAN DARAH PADA PENDERITA HIPERTENSI
}

\author{
Syahida Nur Al Idrus ${ }^{1}$, Nina Gartika ${ }^{2}$, Angga Wilandika ${ }^{3}$ \\ ${ }^{1)}$ STIKes 'Aisyiyah Bandung \\ 2,3) Universitas 'Aisyiyah Bandung \\ nina.gartika@gmail.com
}

\begin{abstract}
ABSTRAK
Hipertensi masih menjadi salah satu penyebab kematian di Indonesia sebanyak $70 \%$ orang menderita hipertensi pada tahun 2018. Salah satu penatalaksanaan untuk mengurangi terjadinya komplikasi pada hipertensi yaitu berupa aktivitas fisik jalan kaki. Penelitian tentang pengaruh jalan kaki terhadap penurunan tekanan darah sudah banyak dilakukan tetapi khusus pada usia dewasa madya dengan durasi tertentu (20 menit) belum pernah dilakukan. Penelitian ini bertujuan untuk mengetahui adanya pengaruh jalan kaki 20 menit terhadap penurunan tekanan darah pada penderita hipertensi. Desain penelitian yang digunakan yaitu kuantitatif dengan jenis quasi experiment without control group preposttest design. Sampel yang terlibat sebanyak 15 orang penderita hipertensi yang diambil secara consecutive sampling. Analisis inferensial yang digunakan adalah uji statistik $t$-test dengan tingkat kemaknaan 0,05. Hasil penelitian menunjukkan bahwa sebagian besar responden berjenis kelamin perempuan $(73,3 \%)$, berpendidikan SD $(46,7 \%)$, bekerja sebagai IRT $(60,0 \%)$, dan memiliki kategori IMT overweight (53,3\%). Hasil uji statistik rerata nilai tekanan darah sistolik dan diastolik setelah perlakuan $(p$-value $=0,000)$. Dapat disimpulkan bahwa terdapat pengaruh jalan kaki 20 menit terhadap penurunan tekanan darah. Saran yang dapat diberikan bahwa jalan kaki 20 menit selama tiga kali seminggu dapat menjadi pilihan sebagai terapi nonfarmakologi dalam menurunkan tekanan darah
\end{abstract}

Kata kunci : hipertensi, jalan kaki, tekanan darah

\begin{abstract}
Hypertension is still one of the causes of death in Indonesia, as many as $70 \%$ of people suffer from hypertension in 2018. One of the management to reduce the occurrence of complications in hypertension is in the form of physical activity on foot. This research told about the effect of walking on decreasing blood pressure has been done a lot but specifically in middle adulthood has never been done, besides that, the duration is still varied. This study aimed to determine the effect of 20 minutes of walking on decreasing blood pressure in patients with hypertension. The research design used is quantitative with the type of quasi-experiment without control group pre-posttest design. The samples involved were 15 people with hypertension who were taken consecutive sampling. The Inferential analysis used is the test statistic test with a significance level of 0.05. The results showed that the characteristics of the respondents were female (73.3\%), elementary school education (46.7\%), worked as a housewife (60.0\%) and had overweight IMT $(53.3 \%)$. The results of statistical tests the average value of systolic and diastolic blood pressure after treatment ( $p$ value $=0.000$ ). It can be concluded that there is an influence of 20 minutes of walking on the decrease in systolic blood pressure. The suggestion that can be given that walking 20 minutes three times a week can be chosen as a nonpharmacological therapy in reducing blood pressure.
\end{abstract}

Keywords: hypertension, walking, blood pressure 


\section{PENDAHULUAN}

Menurut data dari WHO hipertensi menduduki peringkat pertama sebagai penyakit penyebab kematian setiap tahunnya. Sebanyak 1.13 milar orang terkena penyakit hipertensi dengan perbandingan 1 dari 3 orang di dunia menderita hipertensi. Secara global prevalensi hipertensi terjadi pada masa dewasa berusia 25 tahun ke atas sebesar 40\% (World Health Organization, 2019).

Penyakit hipertensi masih menduduki peringkat pertama sebagai prevalensi tertinggi penyakit tidak menular bahkan masih merupakan masalah bagi kesehatan Indonesia. Berdasarkan pelaporan Riskesdas tahun 2018 tercatat bahwa penderita hipertensi mencapai 70\%(Kementrian Kesehatan Republik Indonesia, 2018).

Penatalaksanaan hipertensi meliputi terapi farmakologi dan nonfarmakologi. Keduanya bertujuan untuk mengurangi risiko terjadinya komplikasi pada hipertensi. Beberapa terapi farmakologi dilaporkan menimbulkan efek samping, seperti demam, sakit tenggorokan, rasa lelah, kram otot, pusing, adanya ruam pada kulit, dan jantung berdebar. Selain terapi farmakologi terdapat terapi nonfarmakologi yang disarankan dapat mengurangi gejala hipertensi yaitu modifikasi gaya hidup. Salah satu modifikasi gaya hidup yaitu aktivitas fisik seperti latihan aerobik, seperti: berjalan, jogging, berenang, bersepeda, dan menari (Hasanudin et al., 2018)

Salah satu terapi nonfarmakologi yang dapat dilakukan adalah melakukan olahraga jalan kaki. Jalan kaki sangat ringan, sederhana, ekonomis, dan bisa dilakukan kapan saja dan dimana saja. Penelitian sebelumnya dilakukan terhadap 15 responden penderita hipertensi yang diberikan perlakuan berupa berjalan selama 5 kali dalam seminggu dalam waktu 8 minggu menunjukkan penurunan tekanan darah (Khomarun et al., 2014). Tujuan dari penelitian ini untuk mengetahui pengaruh jalan kaki 20 menit terhadap perubahan tekanan darah pada penderita hipertensi.

\section{METODOLOGI}

Penelitian yang dilakukan yaitu penelitian kuantitatif dengan rancangan quasi experiment without control group pre-posttest design. Penelitian eksperimen yaitu penelitian yang dilakukan untuk mengetahui akibat yang ditimbulkan dari suatu perlakuan yang diberikan dengan satu kelompok intervensi. Teknik pengambilan sampel pada penelitian ini yaitu menggunakan consecutive sampling. Peneliti menentukan responden dengan cara menghitung sampel dan menentukan kriteria inklusi yang ikut serta dalam penelitian ini. Kemudian peneliti melakukan skrining terhadap responden sesuai dengan kriteria inklusi yang sudah ditentukan. Setelah responden bersedia maka responden menandatangani lembar persetujuan yang telah dibuat. Untuk menentukan jumlah sampel dalam penelitian eksperimen menggunakan rumus Dahlan, (2016) komparatif numerik berpasangan pengukuran berulang dua kali pengukuran dengan hasil 15 responden. Peneliti menetapkan kriteria inklusi yaitu responden yang terdiagnosis hipertensi dengan tekanan darah sistolik $\geq 140 \mathrm{mmHg}$ dan tekanan darah diastolik $\geq 90$ $\mathrm{mmHg}$, tidak memiliki kebiasan berolahraga, berusia dewasa madya yaitu dari mulai 40-60 tahun, mengonsumsi obat antihipertensi pada malam hari dan atau tidak mengonsumsi obat antihipertensi, dan memiliki IMT $<30$. Kemudian terdapat kriteria drop out yaitu responden yang tidak selesai mengikuti intervensi jalan kaki 20 menit selama 3 kali dalam satu minggu.

Instrumen pertama dalam penelitian ini menggunakan lembar demografi yang bertujuan untuk mengetahui identitas responden yang berisi nama, jenis kelamin, usia, pendidikan, pekerjaan, alamat, tinggi badan, berat badan, dan indeks massa tubuh. Selain itu, instrumen 
ini berisi tentang faktor-faktor risiko hipertensi, seperti: riwayat keluarga memiliki hipertensi, riwayat mempunyai penyakit lain, kebiasaan mengonsumsi makanan berlemak, kebiasaan mengonsumsi makanan asin atau berpengawet, kebiasaan meminum alkohol, kebiasaan merokok, dan kebiasaan meminum obat antihipertensi. Kemudian instrumen yang kedua yaitu alat sphygmomanometer aneroid digunakan untuk mengukur tekanan darah responden pada saat pretest dan posttest intervensi yang sudah dikalibrasi oleh petugas laboratorium STIKes 'Aisyiyah Bandung, dan instrumen yang terakhir yaitu lembar observasi digunakan untuk mencatat hasil dari tekanan darah responden pada saat pretest dan posttest intervensi. Perlakuan yang diberikan berupa jalan kaki yang dilakukan selama 20 menit. Analisis data menggunakan Uji t-test. Penelitian ini telah mendapatkan persetujuan Komite Etik Penelitian Kesehatan Poltekkes Kemenkes Bandung nomor 08/KEPK/ $\mathrm{PE} / \mathrm{V} / 2019$.

\section{HASIL}

\section{Karakteristik Responden}

Dalam penelitian ini, dilakukan analisis univariat untuk menjelaskan atau mendeskripsikan karakteristik setiap variabel.

Tabel 1. Distribusi Frekuensi Berdasarkan Karakteristik Responden di Wilayah UPT Puskesmas Talaga Bodas $(n=15)$

\begin{tabular}{lll}
\hline Karakteristik & f & $\%$ \\
\hline
\end{tabular}

Usia dalam rentang

dewasa madya (40-60

tahun) rata-rata usia 54

tahun

\section{Jenis Kelamin}

\begin{tabular}{lcc} 
Perempuan & 11 & 73,3 \\
Laki-laki & 4 & 26,7 \\
\hline
\end{tabular}

Pendidikan

Tidak Tamat SD

320,0

\begin{tabular}{|c|c|c|}
\hline Karakteristik & $\mathbf{f}$ & $\%$ \\
\hline Tamat SD & 7 & 46,7 \\
\hline Tamat SMP & 4 & 26,7 \\
\hline Tamat SMA & 1 & 6,7 \\
\hline \multicolumn{3}{|l|}{ Pekerjaan } \\
\hline Ibu Rumah Tangga & 9 & 60,0 \\
\hline Wiraswasta & 1 & 6,7 \\
\hline Buruh & 1 & 6,7 \\
\hline Lainnya & 1 & 6,7 \\
\hline Tidak Bekerja & 3 & 20,0 \\
\hline \multicolumn{3}{|l|}{ IMT } \\
\hline Underweight $(<18,5)$ & 2 & 13,3 \\
\hline Normal $(18,5-24,9)$ & 5 & 33,3 \\
\hline Overweight $(25,0-29,9)$ & 8 & 53,3 \\
\hline \multicolumn{3}{|c|}{ Keluarga Mempunyai Rirawat Hipertensi } \\
\hline Ya & 5 & 33,3 \\
\hline Tidak & 10 & 66,7 \\
\hline \multicolumn{3}{|l|}{ Kebiasan Merokok } \\
\hline Ya & 6 & 40,0 \\
\hline Tidak & 9 & 60,0 \\
\hline \multicolumn{3}{|c|}{ Kebiasaan Mengkonsumsi Makanan Asin } \\
\hline Ya & 8 & 53,3 \\
\hline Tidak & 7 & 46,7 \\
\hline \multicolumn{3}{|c|}{$\begin{array}{l}\text { Kebiasaan Mengkonsumsi Makanan } \\
\text { Berlemak }\end{array}$} \\
\hline Ya & 12 & 80,0 \\
\hline Tidak & 3 & 20,0 \\
\hline \multicolumn{3}{|c|}{ Kebiasaan Meminum Alkohol } \\
\hline Ya & 0 & 0,0 \\
\hline Tidak & 15 & 100,0 \\
\hline \multicolumn{3}{|c|}{ Kebiasaan Meminum Obat Antihipertensi } \\
\hline Ya & 7 & 46,7 \\
\hline Tidak & 8 & 53,3 \\
\hline
\end{tabular}

Tabel di atas menunjukkan bahwa responden berada pada usia dewasa madya (4060 tahun) dengan rata-rata pada usia 54 tahun. Sebagian besar responden berjenis kelamin perempuan $(73,3 \%)$, berpendidikan Sekolah Dasar (SD) (46,7\%), bekerja sebagai ibu rumah tangga (60,0\%), dengan memiliki Indeks Massa Tubuh (IMT) overweight (53,3\%).

Selain itu responden yang tidak 
memiliki riwayat hipertensi dalam keluarganya $(66,7 \%)$, tidak memiliki kebiasaan merokok $(60,0 \%)$, memiliki kebiasaan mengonsumsi makanan berlemak (80,0\%), memiliki kebiasaan mengonsumsi makanan asin (53,3\%), tidak memiliki kebiasaan mengonsumsi obat antihipertensi (53,3\%), dan tidak memiliki kebiasaan mengonsumsi alkohol (100\%).

Gambar 1. Perubahan Tekanan Darah Sistolik Sebelum dan Sesudah Jalan Kaki 20 Menit $(n=15)$

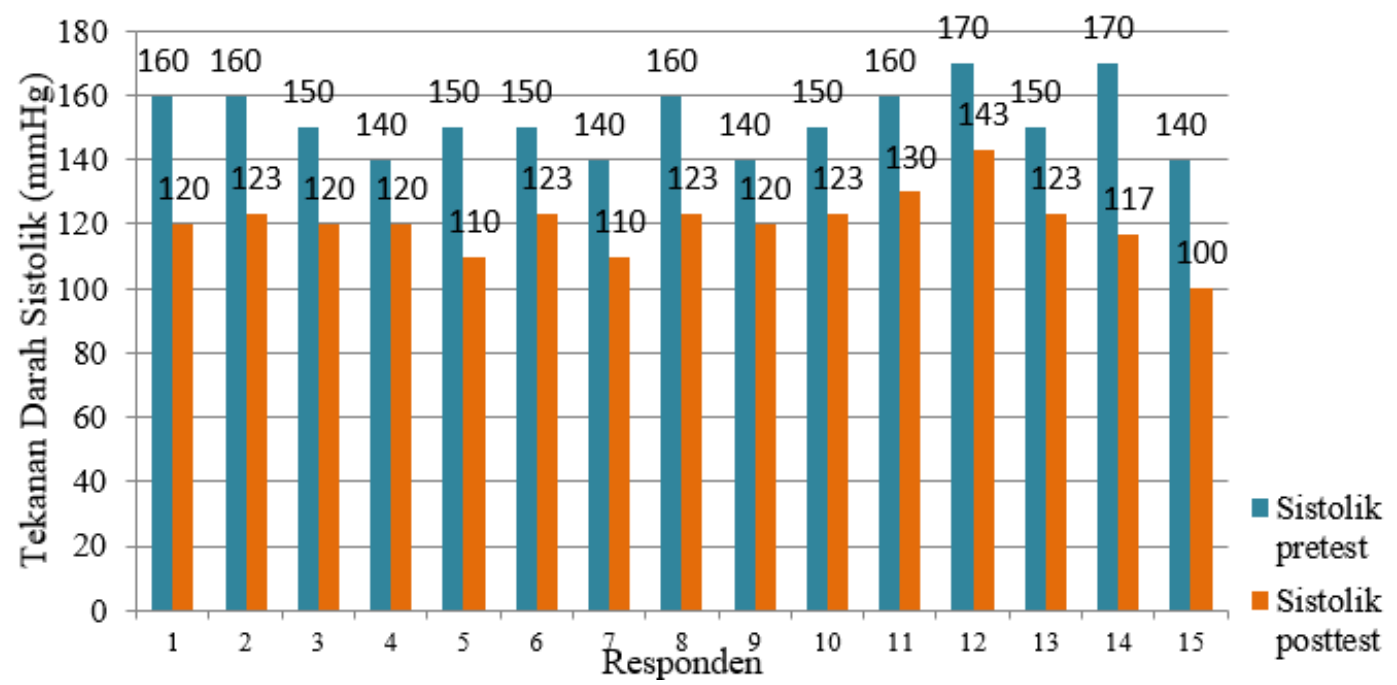

Gambar 1 menunjukkan rerata nilai tekanan darah sistolik sebelum dan sesudah jalan kaki 20 menit. Sebelum perlakuan seluruh responden memiliki tekanan darah sistolik $\geq 140 \mathrm{mmHg}$. Kemudian setelah perlakuan, rerata nilai tekanan darah sistolik responden mengalami penurunan yaitu 2 responden mengalami penurunan sebesar $20 \mathrm{mmHg}$ (responden 4 dan 9), 4 responden mengalami penurunan sebesar $27 \mathrm{mmHg}$ (responden 6, 10, 12, dan 13), 3 responden mengalami penurunan sebesar $30 \mathrm{mmHg}$ (responden 3, 7 dan 11), 2 responden mengalami penurunan sebesar $37 \mathrm{mmHg}$ (responden 2 dan 8), 3 responden mengalami penurunan sebesar $40 \mathrm{mmHg}$ (responden 1, 5, dan 15), dan 1 responden mengalami penurunan sebesar 53 $\mathrm{mmHg}$ (responden 14).

Gambar 2. Perubahan Tekanan darah diastolik sebelum dan sesudah jalan kaki 20 menit $(n=15)$

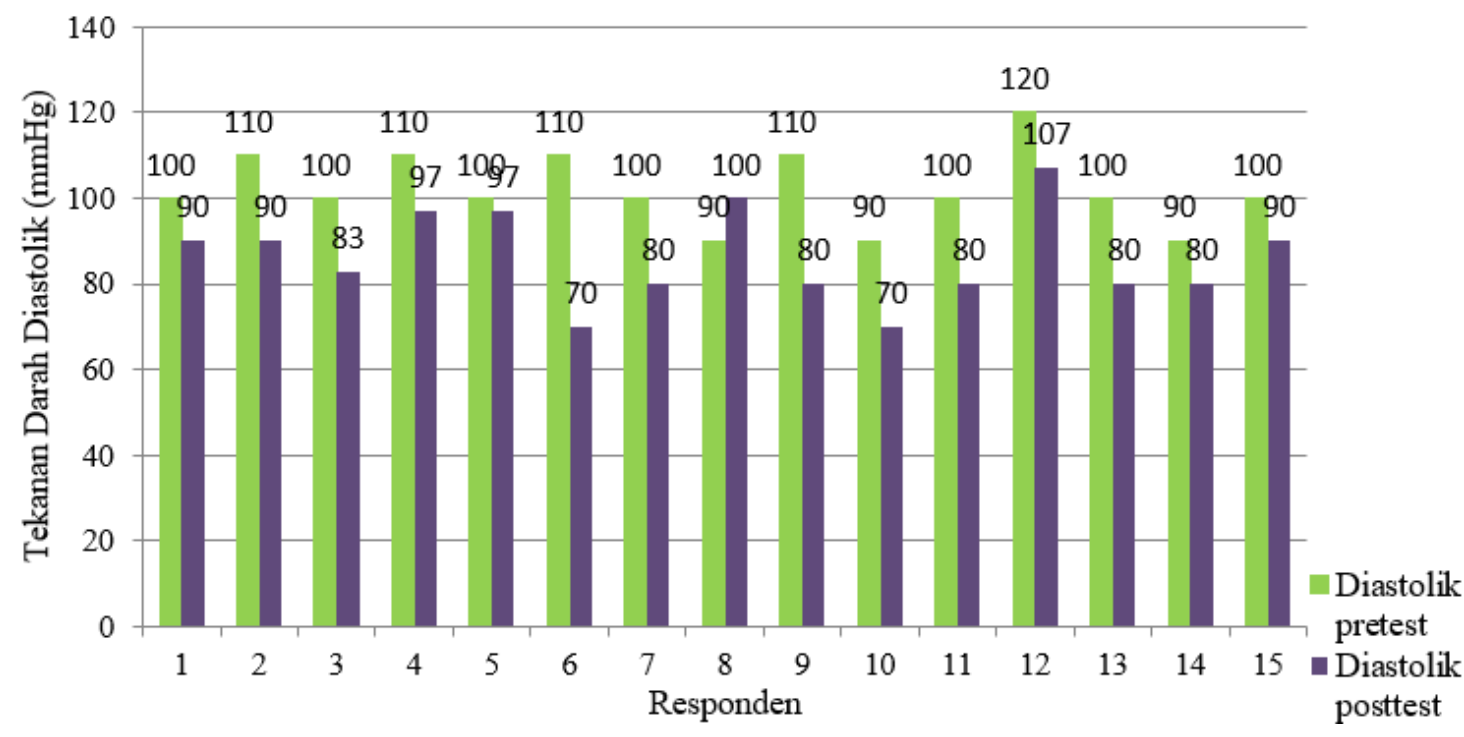


Gambar 2 menunjukkan nilai tekanan darah diastolik sebelum dan sesudah perlakuan. Sebelum perlakuan seluruh responden memiliki tekanan darah sistolik $\geq 90 \mathrm{mmHg}$. Kemudian setelah perlakuan, rerata nilai tekanan darah diastolik responden mengalami penurunan yaitu 1 responden mengalami penurunan sebesar 3 mmHg (responden 5), 3 responden mengalami penurunan sebesar $10 \mathrm{mmHg}$ (responden 1, 14, dan 15), 2 responden mengalami penurunan sebesar $13 \mathrm{mmHg}$ (responden 4 dan 12), 1 responden mengalami penurunan sebesar 17 $\mathrm{mmHg}$ (responden 3), 5 responden mengalami penurunan sebesar $20 \mathrm{mmHg}$ (responden 2, 7, 10, 11, dan 13), 1 responden mengalami penurunan sebesar $30 \mathrm{mmHg}$ (responden 9), 1 responden mengalami penurunan sebesar $40 \mathrm{mmHg}$ (responden 6), dan 1 responden mengalami kenaikan sebesar $10 \mathrm{mmHg}$ (responden 8).

\section{Pengaruh Perlakuan Jalan Kaki 20 Menit Sebelum dan Sesudah Terhadap Tekanan Darah}

Untuk mendapatkan distribusi data maka data analisis bivariat dilakukan uji normalitas. Uji normalitas dilakukan untuk menilai distribusi data pada variabel (Sugiyono, 2016). Terdapat salah satu uji normalitas yaitu menggunakan Uji Shapiro Wilk dengan menggunakan aplikasi komputer SPSS. Uji Shapiro Wilk yaitu uji untuk menghitung kenormalan data yang valid dengan jumlah sampel yang kecil atau $\mathrm{n}<50$ (Dahlan, 2016). Jika nilai sig $<0.05$, maka distribusi tidak normal, namun jika nilai sig $\geq 0.05$, maka distribusi normal.

Tabel 2. Hasil Uji Normalitas dengan Uji Shapiro Wilk

\begin{tabular}{lccc}
\hline \multirow{2}{*}{$\begin{array}{c}\text { Tekanan } \\
\text { Darah }\end{array}$} & \multicolumn{3}{c}{ Shapiro Wilk } \\
\cline { 2 - 4 } & Statistik & df & Sig. \\
\hline Sistolik & .202 & 15 & .056 \\
Pretest & & 15 & .090 \\
Sistolik Posttest & .257 & \\
\hline
\end{tabular}

\begin{tabular}{lccc}
\hline \multirow{1}{*}{$\begin{array}{c}\text { Tekanan } \\
\text { Darah }\end{array}$} & \multicolumn{3}{c}{ Shapiro Wilk } \\
\cline { 2 - 4 } & Statistik & df & Sig. \\
\hline $\begin{array}{l}\text { Diastolik } \\
\text { Pretest }\end{array}$ & .258 & 15 & .050 \\
$\begin{array}{l}\text { Diastolik } \\
\text { Posttest }\end{array}$ & .186 & 15 & .366 \\
\hline
\end{tabular}

Berdasarkan hasil uji normalitas dengan Uji Shapiro Wilk yang sudah dilakukan didapatkan hasil nilai $p$-value $\geq 0,05$, maka data tersebut terdistribusi normal. Jika data terdistribusi normal maka menggunakan analisis uji parametrik paired t-test.

Tabel 3. Pengaruh Perlakuan Jalan Kaki

20 Menit Sebelum dan Sesudah Terhadap

Tekanan Darah $(\alpha$ value $=0,05)$

\begin{tabular}{|c|c|c|}
\hline $\begin{array}{c}\text { Tekanan } \\
\text { Darah }\end{array}$ & Mean \pm SD & p value \\
\hline $\begin{array}{l}\text { Sistolik pre- } \\
\text { test-sistolik } \\
\text { posttest }\end{array}$ & $\begin{array}{c}32,333 \pm \\
8,789\end{array}$ & 0,000 \\
\hline $\begin{array}{l}\text { Diastolik pre- } \\
\text { test-diastolik } \\
\text { posttest }\end{array}$ & $\begin{array}{c}15,733 \pm \\
11,411\end{array}$ & 0,000 \\
\hline
\end{tabular}

Hasil Uji-t test menunjukkan perbedaan rerata tekanan darah sistolik sebelum dan sesudah dilakukan intervensi jalan kaki 20 menit yang bermakna $p$-value $=0,000<\alpha=0,05$ dan rerata tekanan darah diastolik sebelum dan sesudah dilakukan intervensi jalan kaki 20 menit yang bermakna $p$-value $=0,000<\alpha=0,05$. Dari hasil uji tersebut dapat disimpulkan terdapat pengaruh jalan kaki 20 menit terhadap penurunan tekanan darah.

\section{PEMBAHASAN}

\section{Pengaruh Jalan Kaki 20 Menit Terhadap Penurunan Tekanan Darah}

Berdasarkan hasil penelitian di dapatkan $p$-value $=0,000<\alpha=0,05$ dapat disimpulkan terdapat pengaruh jalan kaki 20 menit terhadap penurunan tekanan darah. Hal ini sejalan 
dengan penelitian Surbakti, (2014) terdapat adanya pengaruh latihan jalan kaki 30 menit terhadap penurunan tekanan darah sistolik dan diastoliknya. Penelitiannya belum dapat menurunkan tekanan darah sampai tingkat tekanan darah normal, tetapi hanya memberikan pengaruh terhadap penurunan tekanan darah sistolik dan diastoliknya. Kemungkinan ini dapat disebabkan oleh beberapa faktor antara lain faktor motivasi dari dalam diri pasien yang masih kurang, pola makan pasien yang tidak teratur, adanya pasien yang tidak maksimal sewaktu melakukan latihan atau faktor alam. Hal ini sejalan dengan penelitian Latif, (2013) bahwa responden yang telah diteliti menunjukkan bahwa tidak terjadi perubahan stadium hipertensi yang signifikan. Akan tetapi jika ditinjau dari selisih perubahan TDS pre dan post intervensi secara deskriptif menunjukkan rentang angka yang cukup besar yaitu $0-10 \mathrm{mmHg}$. Hal ini dapat disebabkan oleh beberapa faktor, diantaranya aktivitas berjalan merupakan salah satu aktivitas rekreasional.

Pada penelitian ini terdapat responden yang mencapai penurunan tekanan darah pada batas normal. Hal ini karena seluruh responden yang sedang melakukan jalan kaki 20 menit selalu didampingi oleh peneliti agar responden melakukannya sesuai dengan standar prosedur operasional yang sudah dibuat. Menurut Hanson \& Jones, (2015) jalan kaki yang dilakukan teratur dan cara yang benar dapat memberikan efek penurunan tekanan darah.

Penelitian lain tentang jalan kaki dilakukan oleh Khomarun; Nugroho, Maharso Adhi; Wahyuni, (2014) bahwa terdapat pengaruh pemberian aktivitas berjalan terhadap perubahan tekanan darah. Perubahan (penurunan) tekanan darah yang terjadi sebesar 0-10 mmHg. Hal ini mungkin dapat disebabkan oleh beberapa faktor salah satunya yaitu faktor usia yaitu pada usia lansia. Pada penelitian ini rata- rata usia responden yaitu 54 tahun dengan usia yang diambil pada penelitian ini yaitu usia dewasa madya (40-60 tahun). Menurut Fitriani, Nur; Nilamsari, (2017) orang yang memiliki hipertensi pada usia lansia $\geq 60$ tahun akan sulit mengalami penurunan tekanan darah karena tekanan arterial meningkat sesuai dengan bertambahnya usia, terjadinya regurgitasi aorta, serta adanya generatif yang lebih sering pada usia tua.

Penelitian lain menemukan bahwa terdapat pengaruh jalan pagi terhadap perubahan tekanan darah. Pada saat jalan kaki terutama di pagi hari sangat bermanfaat, antara lain: memperlancar sirkulasi darah, mempertahankan kekuatan otot dan stamina, dan meningkatkan penyerapan vitamin D, sirkulasi darah yang lancar akan memperlancar tekanan darah (Puspitasari, Dian Ika; Hannan, Mujib; Chindy, 2017). Selain itu olahraga secara rutin pada pagi hari merupakan waktu yang tepat untuk melakukan olahraga karena selain kapasitas udara yang masih segar olahraga pagi juga membantu meningkatkan daya konsentrasi manusia ketika melakukan berbagai aktivitas (Khomarun et al., 2014).

Melakukan jalan kaki secara teratur dapat menurunkan tekanan darah 4-8 mmHg, jalan kaki dapat memperlancar peredaran darah sehingga dapat menurunkan tekanan darah (Triangto \& Meidimarjanti, 2014). Hal ini selaras dengan pernyataan Lingga, (2012) bahwa kekuatan otot kaki yang meningkat saat berjalan bermanfaat untuk menambah kebutuhan oksigen ke jantung dan otak. Bagi penderita hipertensi, kebutuhan oksigen yang memadai merupakan syarat penting untuk menjaga kestabilan tekanan darah. Bersama dengan otot yang aktif bergerak teratur, darah yang mengalir di antara jaringan otot semakin lancar. Darah tersebut membawa oksigen dan glukosa yang dibutuhkan sebagai zat pembakar untuk kontraksi otot. Mekanisme seperti ini penting untuk mengatur tekanan darah. 
Latihan jalan kaki dapat memperlancar peredaran darah untuk mengambil, mengedarkan dan menggunakan oksigen serta menaikkan elastisitas pembuluh-pembuluh darah dan jantung akan berkerja secara normal, juga menurunkan kadar lemak dalam darah yang mengendap pada dinding pembuluh darah yang mengakibatkan arterioslerosis. Latihan jalan kaki juga dapat memengaruhi dalam meningkatkan kapiler-kapiler darah, konsentrasi haemoglobin, perbedaan oksigen pada arteri dan vena serta aliran darah pada otot (Surbakti, 2014).

Berjalan dengan teratur dapat mengurangi aktivitas simpatis, meningkatkan tonus vagal yang mengarah pada pengurangan resistensi perifer, dan mengurangi kadar norepinefrin sekitar 30\%. Pengurangan ini dapat menurunkan tekanan darah (Borjesson, Mats; Onerup, Aron; Lundqvist, Stefan; Dahlof, 2016). Selain itu, efek jalan kaki ini juga dapat mengakibatkan pelepasan zat vasodilatasi seperti: endorfin, berkurangnya resistensi insulin dan efek pada fungsi ginjal melalui pengurangan kadar plasmarenin (Mancia, Giuseppe; Fagard, Robert; Narkiewicz, 2013).

Pada saat jalan kaki akan memicu pengaktifan hormon epinefrin yang menyebabkan semakin kuatnya kontraksi otot jantung. Epinefrin akan berikatan dengan reseptor $\beta 2$, jika terjadi pengaktifan reseptor $\beta 2$ akan menimbulkan vasodilatasi. Peningkatan pelebaran atau vasodilatasi pembuluh darah saat latihan juga disebabkan karena meningkatnya suhu tubuh (Sherwood, 2014).

\section{SIMPULAN DAN SARAN}

\section{Simpulan}

Berdasarkan hasil penelitian dapat disimpulkan bahwa terdapat pengaruh jalan kaki 20 menit terhadap penurunan tekanan darah pada penderita hipertensi ( $p$-value $<0,005)$.

\section{Saran}

\section{Bagi Keperawatan}

Hasil dari penelitian ini dapat menjadi evidence based nursing bagi pengembangan intervensi keperawatan medikal bedah khususnya pada pasien hipertensi.

\section{Bagi Responden}

Hasil penelitian ini dapat menjadi alternatif pasien hipertensi dalam mengontrol tekanan darah dan mengurangi ketergantungan terhadap terapi farmakologi.

\section{Bagi Peneliti Selanjutnya}

Hasil penelitian ini diharapkan menjadi data dasar untuk melaksanakan penelitian selanjutnya dalam ruang lingkup yang berbeda, dengan adanya kelompok kontrol, dengan sampel yang lebih besar, dan menggunakan alat untuk mengukur kecepatan, lebar langkah, presisi derajat langkah, dan irama yang homogen.

\section{DAFTAR PUSTAKA}

Borjesson, Mats; Onerup,Aron;Lundqvist, Stefan; Dahlof, B. (2016). Physical Activity And Exercise Lower Blood Pressure In Individuals With Hypertension: Narrative Review Of 27 RCTs. British Journal of Sports Medicine, 50, 356-361.

Dahlan, M. S. (2016). Besar Sampel dalam Penelitian Kedokteran dan Kesehatan (seri 2 edi). Epidemiologi Indonesia.

Fitriani, Nur; Nilamsari, N. (2017). Faktor-faktor yang berhubungan dengan tekanan darah pada pekerja shift dan pekerja non-shift di pt. X gresik. Journal of Industrial Hygiene and Occupational Health, 2(1).

Hanson, S., \& Jones, A. (2015). Is there evidence that walking groups have health bene fits ? A systematic review and meta-analysis. Br J Sports Med, 710-715. https://doi. org/10.1136/bjsports-2014-094157 
Hasanudin, Ardiyani, V. M., \& Purwaningtyas, P. (2018). Hubungan Aktivitas Fisik dengan Tekanan darah pada Masyarakat Penderita Hipertensi Di Wilayah Tlogosuro Kelurahan Tlogomas Kecamatan Lowokwaru Kota Malang. Nursing News, 3 (1), 787-798.

Kementrian Kesehatan Republik Indonesia. (2018). Hasil Utama Riskesdas 2018. https://kesmas.kemkes.go.id/assets/ upload/dir_519d41d8cd98f00/files/ Hasil-riskesdas-2018_1274.pdf

Khomarun, Nugroho, M. A., \& Wahyuni, E. S. (2014). Pengaruh aktivitas fisik jalan pagi terhadap penurunan tekanan darah pada lansia dengan hipertensi stadium i di posyandu lansia desa makamhaji. Jurnal Terpadu Ilmu Kesehatan, 3, 106-214.

Sebuah Survei Menemukan 10 dari 200 Pekerjaan dengan Tingkat Stres Paling Tinggi., (2013).

Lingga, L. (2012). Bebas Hipertensi tanpa Obat. AgroMedia.

Mancia, Giuseppe; Fagard, Robert; Narkiewicz, K. et. all. (2013). 2013 ESH/ESC Guidelines for the management of arterial hypertension The Task Force for the management of arterial hypertension of the European Society of Hypertension (ESH) and of the European Society of Cardiology (ESC). European Heart Journal, 34, 2159-2219. https://doi. org/10.1093/eurheartj/eht151

Puspitasari, Dian Ika; Hannan, Mujib; Chindy, L. D. (2017). Pengaruh jalan pagi terhadap perubahan tekanan darah pada lanjut usia dengan hipertensi di desa kalianget timur kecamatan kalianget kabupaten sumenep. Jurnal Ners LENTERA, 5(2), 169-177.

Sherwood, L. (2014). Fisiologi Manusia dari Sel ke Sistem. EGC.

Sugiyono. (2016). Statistik untuk Penelitian. Alfabeta.

Surbakti, S. (2014). Pengaruh latihan jalan kaki 30 menit terhadap penurunan tekanan darah pada pasien penderita hipertendi di rumah sakit UMUM kabanjahe. JURNAL Pengabdian Kepada Masyarakat, 20.

Triangto, M., \& Meidimarjanti. (2014). Jalan Sehat dengan Sports Therapy. Jakarta: Kompas.

WorldHealth Organization.(2019).Hypertension. https://www.who.int/health-topics/ hypertension/\#tab=tab_1 